\title{
The Absorption of Glucose by Ostrea edulis.
}

\author{
By \\ C. M. Yonge, D.Sc., Ph.D., \\ Balfour Student in the University of Cambridge.
}

With 1 Figure in the Text.

\section{CONTENTS.}

1. Introduction and Literature

2. Methods

3. Experimental Results

4. Discussion

5. Summary .

6. References

1. Introduction and Literature.

IN a series of papers Ranson $(1924,1925,1926,1927)$ has put forward the view that in Lamellibranchs soluble matter is absorbed directly by the epithelia of the gills, palps, mantle and other exposed surfaces in the mantle cavity. It is in this manner, he considers, that the greening of oysters is brought about, the oily green pigment (Marennin) from the diatom Navicula ostrearia being excreted into the water in which it is dissolved and from which it is absorbed in the manner described. He is opposed to the view that the pigment is absorbed in the alimentary canal and then deposited in the epithelium as a result of leucocytic excretion.

Ranson gives very unsatisfactory evidence in support of his views; he has failed to follow the process of absorption in any detail, while he lays great stress on the work of Carazzi $(1896,1897)$ and Churchill $(1915,1916)$. Since in my own work on feeding and digestion of Lamellibranchs, I failed to observe the assimilation of soluble matter in the form of iron saccharate elsewhere than in the digestive diverticula (or occasionally in phagocytes) in Nucula, Cardium, Mya, Teredo (1926a), in larval, spat, and adult Ostrea edulis (1926b), and in Cuspidaria and Poromya (1928), I find it difficult to accept the conclusions of Ranson.

Carazzi thought that Marennin was taken up by the epithelial cells of the gills, palps, and gut, and then passed on to the "liver" where it was assimilated and stored, basing his views on evidence obtained by keeping 
oysters in a solution in sea-water of iron sulphate. But his experimental methods, as List (1902) originally pointed out, are open to the gravest criticism. He kept oysters for four months in three litres of sea-water containing 20 grams of a $10 \%$ solution of iron sulphate in distilled water, and then in clean sea-water for 1-2 weeks before fixing them. By this time the animals were thoroughly permeated with iron which he found in the epithelium of the gills, palps and gut, and in the "liver" ; but he had no better reason for assuming that it had been absorbed by the former and passed on to the latter than that the reverse process had taken place. Churchill, who worked on freshwater mussels, found that after animals had been kept in very dilute solutions of soap, egg albumen, and soluble starch stained with iodine, these substances were found in the epithelial cells of the body, mantle, foot, gills and palps, some being carried away by the blood cells which he observed on occasion between the epithelial cells. Although his experiments were kept up for from 2 to 58 days, yet absorption clearly took place through the mantle surface, because he plugged the mouths of many of his animals with wax, thus preventing the passage of material into the gut and digestive diverticula.

This evidence Ranson accepts as conclusive, while he considers that he has completed Carazzi's evidence. He found that the epithelia in the mantle cavity of white oysters became charged with Marennin, or iron sulphate, after animals from which the stomach had been cut away were kept for 48 hours in sea-water containing these substances in solution. Moreover, he suspended oysters, of which the two valves were held open, in water so that the gills and mantle were under water but the mouth and anus were not, and got similar results.

With the exception of the carnivorous Septibranchs (1928) which feed on large food masses, I have found that in the Lamellibranchs a very important rôle in the absorption of food is played by phagocytes which pass into the gut and ingest food particles (e.g. diatoms, or blood corpuscles of fish on which the animals had been experimentally fed) laden with which they return through the epithelium into the underlying tissues and blood stream (1926a, 1926b). On occasion these phagocytes may also be extruded in great numbers in the mantle cavity, a phenomenon known as " bleeding" (see Orton (1924) p. 55). After an emulsion of olive oil stained red with Nile blue sulphate was injected into the mantle cavity of oysters, it was found (1926b) that the oil had been taken in by phagocytes (and changed to blue in the process, showing that the neutral fats had been converted by the digestive enzymes into fatty acids). Some phagocytes lay free on the surface of the epithelia, but many others had passed back into the epithelia and underlying tissues of the gills, palps, mantle, and other exposed surfaces. In no case was there any evidence of direct absorption by the epithelial cells. Absorption may, therefore, 
occur in the mantle cavity but only, in my opinion, by the intervention of phagocytes. In a letter to me on this subject Prof. E. P. Churchill says, "I suspect your finding, carrying out the details of the behaviour of the phagocytes farther than I was able to do then (i.e. in his work of 1915, 1916) is correct."

It appeared to me necessary that this problem should be approached from a new aspect, and that the capacity of oysters for removing material from solution in sea-water should be tested quantitatively both before and after their mouths had been plugged, and also when they were " bleeding " profusely in the mantle cavity. It was hoped to experiment with a number of substances, proteins and fats as well as carbohydrates, but, owing to lack of time, only glucose has been employed. Mitchell (1916) has already shown that oysters (O. virginica) which have been kept in sea-water containing dissolved glucose greatly increase their reserves of glycogen, the optimum conditions being "(a) duration of glucose feeding 2-3 days: (b) concentration of glucose equal to about $0 \cdot 25 \%$ : and (c) water density not greatly different from that in which the oysters have previously been." He did not attempt to determine how and where the glucose was absorbed.

\section{Methods.}

Ostrea edulis was used for these experiments as it is an animal of exceptional hardiness amongst Lamellibranchs. Since it was necessary for comparative results that a continuous stream of water should be passing through the mantle cavity and through the alimentary canal during the entire course of the experiments, the inhalent and exhalent chambers were opened by means of a drill, a wide semicircle of shell being cut away opposite the palps and anterior end of the gills, and a smaller opening made in the exhalent cavity, care being taken not to damage the tissues. After the operation and subsequent washing, the presence of a through current of water, in by way of the opening in the inherent cavity and out by way of that in the exhalent cavity, was in every case demonstrated by means of carmine. It was also found that after such animals had been kept for one hour in water coloured deeply with methylene blue the stomach contents were blue, showing that a stream of water was passing into the alimentary canal. Animals treated in this way live indefinitely in the Laboratory tanks.

In all experiments the glucose solution was approximately $0 \cdot 2 \%$. In the first experiments tank water was used, and the experiments were kept going for 48 hours; but there was a great growth of bacteria at the end of this period. By using outside sea-water and running the experiments for 36 hours, this difficulty was overcome, the production of bacteria being 
only slight at the end of that period. The experiments were carried out in five straight-sided aquarium jars in each of which was placed four litres of sea-water containing glucose. Two oysters were placed in each jar (it was difficult to get significant differences in 36 hours when one oyster was used) and the water was kept well aerated for the full period of the experiments. Control experiments (to check the possible decomposition of glucose by bacteria), consisting of one litre of glucose solution without oysters, accompanied each set of experiments.

In the first set of experiments normal animals were used, in the second the mouths of the oysters were plugged by covering the palps (the mouth in Ostrea is not exposed) with hot wax which immediately solidified without damaging the tissues. To prevent the wax floating away when the animals were placed in water it was held in place with plasticine, which in turn was secured (and the oysters prevented from moving the plugs by flapping their valves) by string tied tightly round the oyster. In the third set of experiments plugged oysters "bleeding" profusely in the mantle cavity were employed. It was found in the preliminary experiments, where the great growth of bacteria caused the $\mathrm{pH}$ of the water to fall to $6 \cdot 8$, that the oysters " bled " profusely; the attempt was made to repeat this experimentally by lowering the $\mathrm{pH}$ with acid, but without satisfactory results; instead, plugged oysters were induced to "bleed" by leaving them in the Laboratory tanks for 8 days, at the end of which period the mantle cavity contained great masses of leucocytes.

The glucose, both before the experiments and after 12, 24, and 36 hours, was estimated by means of Benedict's solution in both experiments and controls, samples of 50 c.c. being removed for that purpose. The results were later converted into grams of glucose per litre. The $\mathrm{pH}$ was taken at the same time, though only the first and last readings are given in the tables. In every case five experiments and one control were run.

\section{Experimental Results.}

The results are most easily understood by reference to Tables I, II, and III, referring to experiments with normal, plugged, and plugged and "bleeding," oysters respectively. In no case was any decrease in glucose observed in the controls, showing that, in the 36 hours, there is no appreciable action by bacteria. The $\mathrm{pH}$ never fell lower than $7 \cdot 3$ and seldom as low as that. In the case of normal oysters there was a progressive diminution in the amount of glucose: but when the same oysters were plugged there was no change in the amount of glucose present in two experiments and only a slight diminution in the other three, while, after testing the stomach contents of all oysters with Fehling's solution, glucose was detected in one oyster from each of the three latter experimental jars, but not in any of 


\section{TABLE I.}

\section{Normal Oysters in Glucose Solution.}

Five experiments (A-E) and control (K), each experiment consisting of 2 oysters, opened in inhalent and exhalent chambers, in 4 litres of sea-water containing about $0 \cdot 2 \%$ glucose in solution.

\begin{tabular}{|c|c|c|c|c|c|c|c|}
\hline \multirow[b]{2}{*}{ A } & \multirow{2}{*}{$\begin{array}{c}\mathrm{pH} \\
\text { before. } \\
8 \cdot 0\end{array}$} & \multicolumn{4}{|c|}{ 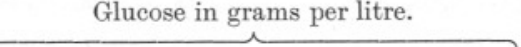 } & \multirow{2}{*}{$\begin{array}{c}\text { Total } \\
\text { decrease } \\
0 \cdot 155\end{array}$} & \multirow{2}{*}{$\begin{array}{c}\mathrm{pH} \\
\text { after } 36 \text { hrs. } \\
7 \cdot 4\end{array}$} \\
\hline & & $\begin{array}{c}\text { before. } \\
2.041\end{array}$ & $\begin{array}{c}12 \mathrm{hrs} \text {. } \\
2 \cdot 0\end{array}$ & $\begin{array}{l}24 \mathrm{hrs} . \\
\mathrm{l} \cdot 95 \mathrm{l}\end{array}$ & $\begin{array}{l}36 \mathrm{hrs} . \\
1.886\end{array}$ & & \\
\hline B & $8 \cdot 0$ & $2 \cdot 041$ & $2 \cdot 0$ & $1 \cdot 887$ & $1 \cdot 835$ & $0 \cdot 206$ & $7 \cdot 3$ \\
\hline C & 8.0 & $2 \cdot 051$ & $2 \cdot 02$ & 1.961 & $1 \cdot 923$ & $0 \cdot 128$ & $7 \cdot 4$ \\
\hline D & 8.0 & $2 \cdot 051$ & $2 \cdot 01$ & $1 \cdot 932$ & $1 \cdot 878$ & $0 \cdot 173$ & $7 \cdot 3$ \\
\hline E & 8.0 & 2.062 & $2 \cdot 02$ & $1 \cdot 942$ & $1 \cdot 887$ & $0 \cdot 175$ & $7 \cdot 3$ \\
\hline K & $8 \cdot 0$ & $2 \cdot 062$ & $2 \cdot 062$ & $2 \cdot 062$ & $2 \cdot 062$ & 0 & $7 \cdot 8$ \\
\hline
\end{tabular}

\section{TABLE II.}

\section{Plugged Oysters in Glucose Solution.}

Same procedure as in Experiment I, same animals used, but mouths plugged with paraffin wax held in place by plasticine and string.

\begin{tabular}{|c|c|c|c|c|c|c|c|}
\hline \multirow[b]{3}{*}{ A } & \multirow{3}{*}{$\begin{array}{c}\mathrm{pH} \\
\text { before. } \\
8 \cdot 0\end{array}$} & \multicolumn{4}{|c|}{ Glucose in grams per litre. } & \multirow{2}{*}{\multicolumn{2}{|c|}{$\begin{array}{c}\text { Total } \\
\text { decrease. after } 36 \text { hrs. }\end{array}$}} \\
\hline & & before. & $12 \mathrm{hrs}$. & $24 \mathrm{hrs}$. & 36 hrs. & & \\
\hline & & $1 \cdot 961$ & $1 \cdot 961$ & 1.942 & $1 \cdot 932$ & $0.029 *$ & $7 \cdot 5$ \\
\hline $\mathrm{B}$ & $8 \cdot 0$ & 1.961 & $1 \cdot 961$ & 1.961 & 1.961 & 0 & $7 \cdot 5$ \\
\hline $\mathrm{C}$ & $8 \cdot 0$ & $2 \cdot 02$ & 1.98 & $1 \cdot 98$ & $1 \cdot 961$ & $0 \cdot 059^{*}$ & $7 \cdot 6$ \\
\hline D & $8 \cdot 0$ & $2 \cdot 02$ & $1 \cdot 98$ & 1.98 & $1 \cdot 961$ & $0.059 *$ & $7 \cdot 6$ \\
\hline $\mathrm{E}$ & $8 \cdot 0$ & 1.99 & $1 \cdot 99$ & $1 \cdot 99$ & $1 \cdot 99$ & 0 & $7 \cdot 7$ \\
\hline K & $8 \cdot 0$ & $1 \cdot 99$ & $1 \cdot 99$ & $1 \cdot 99$ & $1 \cdot 99$ & 0 & $7 \cdot 8$ \\
\hline
\end{tabular}

\section{TABLE III.}

\section{Plugged and "Bleeding" Oysters in Glucose Solution.}

Same procedure as in Experiments I and II, but oysters plugged for 8 days before and, as a result, "bleeding " profusely in mantle cavity.

\begin{tabular}{|c|c|c|c|c|c|c|c|}
\hline \multirow[b]{2}{*}{ A } & \multirow{2}{*}{$\begin{array}{c}\mathrm{pH} \\
\text { before. } \\
8 \cdot 0\end{array}$} & \multicolumn{4}{|c|}{ Glucose in grams per litre. } & \multirow{2}{*}{$\begin{array}{c}\text { Total } \\
\text { decrease. } \\
0.141\end{array}$} & \multirow{2}{*}{$\begin{array}{c}\mathrm{pH} \\
\text { after } 36 \mathrm{hrs} . \\
7.85\end{array}$} \\
\hline & & $\begin{array}{l}\text { before. } \\
2.083\end{array}$ & $\begin{array}{c}12 \mathrm{hrs} . \\
2 \cdot 041\end{array}$ & $\begin{array}{l}24 \mathrm{hrs} . \\
2 \cdot 0\end{array}$ & $\begin{array}{l}36 \mathrm{hrs} . \\
1.942\end{array}$ & & \\
\hline $\mathrm{B}$ & $8 \cdot 0$ & $2 \cdot 083$ & $2 \cdot 041$ & $1 \cdot 942$ & $1 \cdot 914$ & $0 \cdot 169$ & $7 \cdot 5$ \\
\hline C & $8 \cdot 0$ & $2 \cdot 083$ & $2 \cdot 03$ & $2 \cdot 0$ & 1.961 & $0 \cdot 1 \leqslant 2$ & $7 \cdot 8$ \\
\hline D & $8 \cdot 0$ & $2 \cdot 083$ & $2 \cdot 041$ & $1 \cdot 961$ & $1 \cdot 896$ & $0 \cdot 187$ & $7 \cdot 9$ \\
\hline E & $8 \cdot 0$ & $2 \cdot 083$ & $2 \cdot 02$ & $1 \cdot 951$ & $1 \cdot 932$ & $0 \cdot 151$ & $7 \cdot 8$ \\
\hline K & $8 \cdot 0$ & $2 \cdot 083$ & $2 \cdot 083$ & $2 \cdot 083$ & $2 \cdot 083$ & 0 & $8 \cdot 0$ \\
\hline
\end{tabular}

* Glucose detected by means of Fehling's solution in stomach of one oyster in each of these experiments; no sugar in stomachs of other seven oysters. 
the other seven oysters. Thus there is evidence that the slight diminution was due to the passage of glucose into the alimentary canal and its subsequent absorption in the digestive diverticula. There was no evidence of " bleeding" in these oysters after 36 hours. In the case of plugged and "bleeding" oysters a very marked diminution in the quantity of glucose was noted, almost as great as in the case of normal oysters, but in no case did an examination of the stomach contents reveal the presence of sugar.

\section{TABLE IV.}

Comparison of Percentage Amounts of Glucose removed from Solution in 36 hours by Oysters under Different Conditions.

\begin{tabular}{|c|c|c|c|}
\hline & \multicolumn{2}{|c|}{ Same Oysters. } & \multirow[b]{2}{*}{$\begin{array}{c}\text { Plugged and " Bleeding." } \\
6.77\end{array}$} \\
\hline $\mathrm{A}$ & $\begin{array}{c}\text { Normal. } \\
7.59\end{array}$ & $\begin{array}{c}\text { Plugged. } \\
1 \cdot 48\end{array}$ & \\
\hline B & $10 \cdot 09$ & 0 & $8 \cdot 12$ \\
\hline C & $6 \cdot 24$ & $2 \cdot 92$ & $5 \cdot 86$ \\
\hline $\mathrm{D}$ & $8 \cdot 43$ & $2 \cdot 92$ & $8 \cdot 98$ \\
\hline $\mathrm{E}$ & $8 \cdot 49$ & 0 & $7 \cdot 25$ \\
\hline Average & $8 \cdot 17$ & $1 \cdot 46$ & $7 \cdot 40$ \\
\hline K & 0 & 0 & 0 \\
\hline
\end{tabular}

In Table IV the experimental results are compared, and the differences in the percentage amounts of glucose removed from solution by oysters under different conditions shown. In the graph shown in Fig. 1, on page 649 , the percentage decrease in glucose is plotted against the time for all five sets of experiments (A-E) under the three different experimental conditions, and the differences very strikingly displayed. The results of the normal and plugged experiments are directly comparable as the same animals were employed, but, though different animals had to be used for the plugged and " bleeding." experiments, the results are introduced into the graph for the sake of completeness.

The results given above are those of final experiments which confirmed the results obtained from a series of preliminary experiments.

\section{Discussion.}

The above results show clearly that, though two normal oysters may remove from $6 \cdot 24$ to $10 \cdot 09$ per cent of the glucose in 36 hours, either no glucose or very slight quantities are absorbed after the mouths of the oysters have been plugged, and the slight degree of absorption in three 


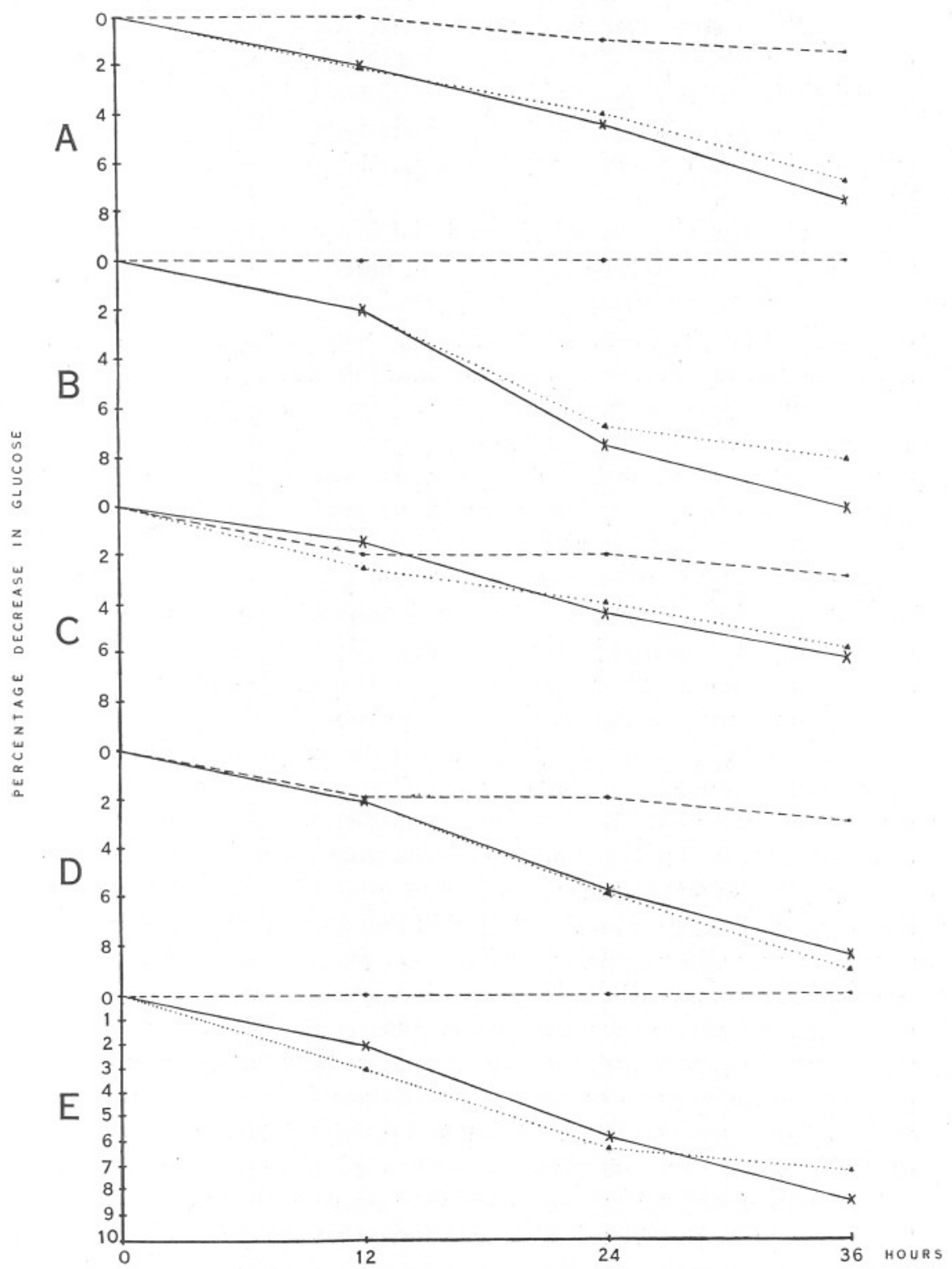

FIG. 1. Graph showing percentage decrease in dissolved glucose up to 36 hours in five sets of experiments (A-E), two oysters being used in each, under three different conditions, normal, plugged, and plugged and " bleeding," the same oysters being used in the normal and plugged experiments.

— Normal. -.-.- Plugged. N............ Plugged and "Bleeding." 
cases is probably due to incomplete blocking of the mouth. These results are entirely in agreement with previous feeding experiments with iron saccharate, which showed that absorption of soluble matter takes place exclusively in the tubules of the digestive diverticula. Absorption in the remainder of the gut is carried on exclusively by the agency of phagocytes, which are concerned with solid particles rather than matter in solution.

From the digestive diverticula material is transported by leucocytes throughout the body especially, if it be of nutritive value, to the gonads. But if it is waste material (such as Marennin) then, if absorbed in large quantities, it may not all be disposed of by way of the excretory organs (which do not appear very efficient in Lamellibranchs), but be deposited in the epithelial cells lining the alimentary canal and mantle cavity. The presence of pigmented granules in such cells is no indication that they have been absorbed by the cells. Thus the stomach epithelium of Nucula (1926a) is frequently found gorged with them although iron saccharate is absorbed exclusively in the digestive diverticula, while in Cuspidaria and Poromya (1928), where the stomach cells are invariably packed with brown or yellowish granules, absorption is impossible owing to the thick cuticle which everywhere lines the stomach. In the Gastropod, Trochus, also, I have found the epithelium of the stomach packed with green globules, but, there again, iron saccharate was absorbed exclusively in the digestive diverticula. In all cases, probably, these granules represent excretory matter deposited in the epithelial cells by leucocytes in much the same way as the products of the digestion of the blood corpuscles fed to oysters are passed on to the epithelial cells from the phagocytes (1926b).

Nevertheless material may be absorbed directly in the mantle cavity, as shown by the experiments of Churchill and Ranson where the alimentary canal was either securely blocked, removed, or else raised above the solution. The explanation of this, as I indicated above, is to be found in the presence of phagocytes free in the mantle cavity. This view receives the strongest support from the experiments on plugged and "bleeding" oysters. In no case was sugar detected in their stomachs, yet from $5 \cdot 86$ to $8.98 \%$ of glucose was removed by two oysters in 36 hours. In every case the mantle cavity contained countless millions of extruded phagocytes which formed whitish masses on the surface of the mantle and gills. There is good reason, therefore, for assuming that the glucose is absorbed by these phagocytes, since the epithelia in the mantle cavity have been shown to be incapable of absorbing. We know little, unfortunately, of the conditions causing " bleeding " in Lamellibranchs, but unfavourable conditions, such as high temperature, being kept for a day or more out of water-especially in warm weather (Orton (1. c.) p. 59) - or in water of low $\mathrm{pH}$, or with their mouths plugged for long periods, undoubtedly cause 
it. In the experiments of Churchill (where freshwater bivalves were kept for long periods with their mouths plugged) and of Ranson (where the alimentary canal was cut away, or oysters suspended half out of water) the conditions were so abnormal that " bleeding ", to a greater or less extent, most probably occurred. The phagocytes so extruded would ingest solid material or absorb soluble matter (as I found in the case of olive oil), and some of them would make their way back into the tissues. This I consider to be the true explanation of these experimental results. It is not impossible that Marennin may be absorbed in this manner in the " claires " at Marennes, where the temperature and salinity of the water both become exceptionally high in the periods between spring-tides, thus possibly causing extensive " bleeding " in the oysters. In other cases the Marennin is probably absorbed in the digestive diverticula and thence transported to all free surfaces by the leucocytes.

The great importance of leucocytes in the mantle fluid of Lamellibranchs has recently been emphasised by Jatzenko (1928), who has approached the problem from the very different aspect of respiration and found that an important part in the process of respiration in freshwater Lamellibranchs is played by the leucocytes. Gorka (1916) stated that the gill mucus of Anodonta and Unio contains enzymes capable of digesting a variety of substances and, as previously pointed out (1926b), the enzymes he found were probably derived from phagocytes in the mucus.

Reference may be made, in conclusion, to the work of Hatt (1926), who states that Indian ink is taken in phagocytically by the epithelium of the gills and palps of Lamellibranchs. Indian ink undoubtedly appears in the epithelia after animals have been in a suspension of ink for several weeks, but this was observed by List and attributed by him, probably correctly, to the action of leucocytes which carried it from the digestive diverticula where it is freely absorbed, as recently confirmed by Vonk (1924). Hatt, however, claims that the ink is taken in directly by the ciliated epithelium because, when he cut off pieces of gill and palp and placed them in water containing Indian ink, he found this in the cells after some six hours. I have repeated his experiments, using the tissues of Ostrea edulis, and found that, under these circumstances, many phagocytes appear on the surface of the epithelium, a large number of them gorged with Indian ink. Others, similarly laden, were seen, after sectioning, between the cells of the epithelium and in the blood stream. Ink was occasionally to be seen in the epithelial cells, but there was no evidence that it was directly ingested; it is, in view of the evidence outlined in this paper, far more probable that it was deposited there by phagocytes.

Acknowledgments are due to the Director and Staff of the Plymouth Laboratory for the provision of facilities for this research, and especially 
to my wife, without whose constant help it would have been impossible, in the limited time at my disposal, to have completed the experiments and prepared the manuscript for the Press.

\section{SUMMARY.}

1. Normal healthy oysters with openings drilled in both inhalent and exhalent chambers, remove considerable amounts of glucose from solution. The average diminution in 5 experiments, each consisting of two such animals kept in 4 litres of sea-water containing about $0.2 \%$ of glucose, was $8 \cdot 17 \%$ at the end of 36 hours.

2. In similar experiments, using the same oysters after their mouths had been plugged with wax and plasticine, there was only an average diminution of $1.46 \%$ in the glucose at the end of 36 hours. In two of the experiments there was no diminution, and in the three others there was evidence that one of the two oysters in each had been incompletely plugged and glucose had passed into the alimentary canal.

3. Oysters which had been plugged for 8 days so that they were "bleeding" profusely, the mantle cavity containing vast numbers of leucocytes, were used for a third set of experiments in which the average diminution was $7 \cdot 4 \%$ at the end of 36 hours.

4. There was no evidence of bacterial decomposition of glucose within the experimental period.

5. These results, taken with those of previous investigations, show that the ciliated epithelia of Lamellibranchs cannot absorb (nor ingest phagocytically). Absorption takes place in the tubules of the digestive diverticula within the alimentary canal, and, in the mantle cavity, only through the agency of phagocytes which are extruded in great numbers when Lamellibranchs " bleed " as a result of bad conditions.

6. The opinion of Ranson that Marennin and other soluble matter is absorbed directly by the ciliated epithelia in the mantle cavity cannot be upheld, this material being deposited in the cells by the phagocytes which either absorb it directly from the mantle cavity and gut, or transport it from the digestive diverticula.

\section{REFERENCES.}

Carazzi, D. 1896. Ricerche sulle Ostriche verdi. Mitth. Zool. Stat. Neapel, 12, p. 381.

Carazzi, D. 1897. Ricerche sull' assorbimento del ferro nel' Ostrea edulis L. Internat. Monatsschr. Anat. Hist., 14, p. 117. 
Churchill, E. P. 1915. The Absorption of Fat by Freshwater Mussels. Biol. Bull., 29, p. 68.

Churchill, E. P. 1916. The Absorption of Nutriment from Solution by Freshwater Mussels. Journ. Exp. Zool., 21, p. 403.

Gorka, S, 1916. Über die Rolle der Kiemen und Mundlappen der heimischen Süsswassermuscheln bei der Ernährung. Alatt. Közlem, Budapest, 15, p. 281.

НАтт, P. 1926. L'absorption d'encre de Chine par les branchies d'Acéphales. Arch. Zool. Expér. et Gén. Notes et Revue, 65, p. 89.

Jatzenko, A. T. 1928. Die Bedeutung der Mantelhöhlenflüssigkeit in der Biologie der Süsswasserlamellibranchier. Biol. Zentralb., 48, p. 1.

List, T. 1902. Die Mytiliden. Fauna und Flora des Golfes von Neapel, $2 \%$.

Mitcheld, P. H. 1916. Nutrition of Oysters: Glycogen Formation and Storage. Bull. U.S.B.F., 35, p. 151.

Orton, J. H. 1924. An Account of Investigations into the Cause or Causes of the unusual Mortality among Oysters in English Oyster Beds during 1920 and 1921. Fishery Investigations, Series II, 6, No. 3 .

Ranson, G. 1924. Note Préliminaire sur le Verdissement des Huîtres. Bull. Soc. Zool., France, 49, p. 512.

Ranson, G. 1925. La Verdissement des Huîtres. C.R. Soc. Biol., 93, p. 1100.

Ranson, G. 1926. La Nutrition chez les animaux aquatiques. C.R. Acad. Sci., Paris, 182, p. 1102.

Ranson, G. 1927. L'Absorption de Matières Organiques dissoutes par la Surface Extérieure du Corps chez les Animaux Aquatiques. Ann. Inst. Océan. Monaco, 4, p. 49.

Vonk, H. J. 1924. Verdauungsphagocytose bei den Austern. Zeit. vergl. Physiol., 1, p. 607.

Yonge, C. M. 1926a. The Digestive Diverticula in the Lamellibranchs. Trans. Roy. Soc., Edin., 54, p. 703.

Yonge, C. M. 1926b. Structure and Physiology of the Organs of Feeding and Digestion in Ostrea edulis. Journ. Mar. Biol. Assoc., 14, p. 295.

Yonge, C. M. 1928. Structure and Function of the Organs of Feeding and Digestion in the Septibranchs, Cuspidaria and Poromya. Phil. Trans. Roy. Soc., Lond., B, 216, p. 221. 
